\title{
Institutionalizing Pancasila Values as Strengthening National Character through Standardization of Materials and Methods of Fostering Pancasila Ideology in Informal Education (Family and Society)
}

\author{
Lestanta Budiman', Hastangka²
}

Pusat Studi Pancasila, UPN Veteran Yogyakarta ${ }^{1,2}$

lestantabudiman@upnyk.ac.id ${ }^{1}$, hastangka@gmail.com²

\section{Article History}

accepted 23/03/2021

approved 10/10/2021

published 20/04/2021

\begin{abstract}
The values of Pancasila were introduced as the living values of the community, nation, and state since Pancasila was laid as the foundation of the state and the nation's outlook on life. From the axiological aspect, the values of Pancasila have existed for hundreds of years. These values are then documented in the form of a formula called Pancasila. In the aspect of social, national, and state life, the values of Pancasila began to be institutionalized formally with general standards and criteria by a government policy known as the Pedoman Penghayatan dan Pengamalan Pancasila (P4) containing the guidelines for living and practicing Pancasila values in the 1978s. The implementation of the policy resulted in the formulation of criteria and general standards of Pancasila values known as points of Pancasila. In the period, there were 36 points of Pancasila formulated. Those points of Pancasila are the foundation and guideline in shaping the characters of the citizens, state administrators, and the youth. Ironically, these criteria and standards were abolished in the 1999 reform period. This study will reformulate the institutionalization of Pancasila values for strengthening the national character through standardization of materials and methods of fostering Pancasila ideology in informal education (in family and community). This study was conducted in 2020 through literature studies, focus group discussions with communities, families, and family education experts. The result of this study shows that the institutionalization of Pancasila values in the community and families can be implemented through 8 functions of structural and non-structural families in form of socialization, cultural art media, and innovative methods.
\end{abstract}

Keywords: Pancasila, values, character, material, methods, institutionalization.

Abstrak

Nilai nilai Pancasila mulai diperkenalkan sebagai living values (nilai kehidupan) bermasyarakat, berbangsa, dan bernegara sejak Pancasila diletakkan sebagai dasar negara dan pandangan hidup bangsa. Dari aspek aksiologis, nilai nilai Pancasila telah ada dalam kehidupan masyarakat ratusan tahun lamanya. Nilai nilai tersebut kemudian dikristalisasikan dalam bentuk formula yang disebut Pancasila. Pada aspek kehidupan bermasyarakat, berbangsa, dan bernegara, nilai nilai Pancasila mulai dilembagakan dalam bentuk formil dengan standar dan kriteria umum melalui kebijakan pemerintah yang dikenal dengan Pedoman Penghayatan dan Pengamalan Pancasila (P4) pada tahun 1978an. Hasil kebijakan ini telah merumuskan kriteria dan standar umum nilai nilai Pancasila yang dikenal sebagai butir butir Pancasila. Pada periode ini dikenal 36 butir butir Pancasila. Butir butir Pancasila tersebut menjadi dasar dan pedoman dalam pembentukan karakter bangsa bagi masyarakat, penyelenggara negara, dan generasi muda. Ironisnya, kriteria dan standar tersebut telah dihapuskan pada periode reformasi 1999. Kajian ini akan melakukan reformulasi atas pelembagaan nilai nilai Pancasila sebagai penguat karakter bangsa melalui standarisasi materi dan metode pembinaan ideologi Pancasila pada pendidikan informal (masyarakat dan keluarga). Studi ini dilakukan pada periode tahun 2020 melalui studi literatur, Focus Group Discussion dengan masyarakat, keluarga, dan pakar pendidikan keluarga. Hasil kajian ini menunjukkan bahwa pelembagaan nilai nilai Pancasila dalam kehidupan masyarakat dan keluarga dapat dilakukan melalui 8 fungsi keluarga struktural dan non struktural dalam bentuk kegiatan sosialisasi, media seni budaya, dan metode inovatif. Kata kunci : Pancasila, nilai, karakter, materi, metode, pelembagaan

Social, Humanities, and Education Studies (SHEs): Conference Series https://jurnal.uns.ac.id/shes 


\section{PENDAHULUAN}

Keluarga menjadi bagian penting dalam keberlangsungan sebuah Negara. Negara yang kuat didukung oleh keluarga yang kuat. Keluarga yang kuat dapat terwujud ketika memenuhi beberapa indikator antara lain ekonomi yang tangguh, kesehatan yang baik, dan ketangguhan mental dalam mewujudkan ketahanan keluarga. Dalam kehidupan berbangsa dan bernegara keluarga memiliki peran penting untuk membangun masyarakat yang berkarakter, berjati diri,dan berkebudayaan.Ketangguhan keluarga ini menjadi batu uji bagi suatu Negara, apakah Negara cukup kuat melahirkan generasi bangsa yang berkualitas, tangguh,dan memiliki jati diri atau sebaliknya. Ketangguhan keluarga menjadi bagian penting untuk mencegah berbagai macam ancaman dan gangguan yang terjadi seperti ancaman lunturnya nilai nilai moral, ancaman terhadap hilangnya jati diri generasi muda, ancaman terhadap bahaya penyalahgunaan obat obat terlarang (narkoba), dan ancaman terhadap gerakan radikalisme yang berpotensi pada tindak kekerasan dan terorisme. Direktorat Pembinaan Pendidikan Keluarga Ditjen PAUD Dan Pendidikan Masyarakat Kementerian Pendidikan Dan Kebudayaan 2017 memberikan gambaran dan dasar dasar pentingnya pendidikan keluarga karena pendidikan keluarga merupakan bagian penting dalam proses pembentukan karakter dan memiliki pengaruh yang besar. Munculnya berbagai macam ancaman dari luar dan dalam menjadikan pendidikan keluarga penting untuk ditanamkan nilai nilai yang baik dan benar. Pendidikan tidak hanya diletakkan pada sekolah dan masyarakat tetapi juga keluarga.

Upaya untuk mempersiapkan generasi yang kuat dan Negara yang tangguh diperlukan peran serta keluarga untuk membangun kualitas keluarga yang memiliki karakter dan jati diri yang tangguh sesuai dengan nilai- nilai Pancasila. Secara umum terdapat 4 karakteristik keluarga yaitu: 1 . Keluarga yang tersusun oleh beberapa orang yang disatukan dalam suatu ikatan seperti perkawinan, hubungan darah, atau adopsi. 2. Anggota keluarga hidup dan menetap secara bersama-sama di suatu tempat atau bangunan di bawah satu atap dalam susunan satu rumah tangga. 3. Setiap anggota keluarga saling berinteraksi, berkomunikasi,dan menciptakan peran sosial bagi setiap anggota seperti; suami, dan istri, ayah dan ibu, putera dan putri, saudara laki laki dan perempuan, dan sebagainya. 4 hubungan antar anggota keluarga merupakan representasi upaya pemeliharaan pola pola kebudayaan bersama yang diperoleh dari kebudayaan umum di komunitas.

Fenomena kehidupan masyarakat dan kehidupan berbangsa dan bernegara 10 tahun terakhir ini, diperhadapkan pada fenomena munculnya berbagai macam perubahan sosial dan politik yang mengarahkan pada menurunnya kualitas hidup dan ketahanan keluarga. Indikasi ini dapat terlihat dari maraknya gerakan politik yang melibatkan keluarga, anak-anak, dan perempuan dalam kegiatan demonstrasi atau aksi politik. Selain itu, munculnya berbagai macam fenomena keterlibatan keluarga dalam tindak kejahatan tersistematis seperti terorisme, aksi bom bunuh diri yang melibatkan perempuan, anak-anak, dan satu keluarga. Aksi peredaran narkoba, dan tindak kejahatan lainnya. Persoalan ini menjadi catatan dalam proses kehidupan berbangsa dan bernegara, dimana peran dan posisi keluarga mulai kehilangan orientasi dan arah dalam mendukung tercapainya Negara yang kuat, tangguh,dan sejahtera. Bertitik tolak dari fenomena ini, kajian ini dilakukan untuk membahas tentang materi dan metode untuk menanamkan kembali Pancasila sebagai wujud untuk memperkuat nilai nilai keluarga dan karakter kebangsaan yang semakin pudar oleh karena perubahan sosial dan politik yang terjadi selama lebih dari 10 tahun ini. Kegiatan yang dilakukan ialah melakukan standarisasi materi, dan metode penanaman nilai-nilai Pancasila di lingkungan keluarga dan masyarakat dalam kerangka program Pembinaan Ideologi Pancasila di Indonesia. 
Proses untuk melakukan pembinaan dan pengguatan peran dan fungsi keluarga dan masyarakat dalam mengawal dan memperkuat nilai nilai Pancasila menjadi penting. Kajian untuk melakukan standarisasi materi dan metode penanaman dan penguatan nilai nilai Pancasila di lingkungan keluarga dan masyarakat menjadi penting. Selama ini pendidikan informal masih belum mendapatkan perhatian secara maksimal untuk menanamkan nilai nilai Pancasila. Berdasarkan studi sebelumnya menunjukkan isu isu pendidikan karakter terkait Pancasila banyak diletakkan pada pendidikan formal seperti studi Octavia dan Rube'i (2017) memfokuskan pendidikan karakter untuk mahasiswa menjadi warga negara baik dan cerdas;Omeri (2015) menekankan studi pentingnya pendidikan karakter dalam dunia pendidikan. Dunia pendidikan yang dimaksud ialah mengarah pada pendidikan formal;Hamid (2012) peran pendidikan untuk mengukuhkan nasionalisme dan membangun karakter bangsa. Aspek pendidikan menjadi penting karena pendidikan sebagai upaya sistematis, terencana dan sadar dalam membangun karakter melalui nilai nilai yang hendak ditanamkan. Keluarga menjadi ujung tombak dalam pembentukan masyarakat dan negara secara umum. Kajian ini bertujuan untuk mendapatkan gambaran tentang standarisasi materi dan metode menanamkan nilai nilai Pancasila dalam kerangka upaya pembinaan Ideologi Pancasila pada pendidikan informal yang dapat diterapkan dan digunakan sebagai acuan dasar dalam kehidupan berbangsa dan bernegara. Untuk itu, kajian tentang penguatan nilai nilai Pancasila dalam kehidupan keluarga menjadi penting.

\section{METODE}

Metode kajian ini menggunakan pendekatan kualitatif. Studi kualitatif tentang standarisasi materi dan metode menanamkan nilai nilai Pancasila dalam rangka pembinaan Ideologi Pancasila pada pendidikan informal (masyarakat dan keluarga). Kajian ini akan melakukan studi literatur (literature review) dari penelitian dan studi sebelumnya tentang materi dan metode pembinaan ideologi Pancasila. Penelitian ini merupakan salah satu bagian dari penelitian yang sudah dilakukan tahun 2020 bekerjasama dengan Badan Pembinaan Ideologi Pancasila (BPIP). Studi yang pernah dilakukan sebelumnya dalam mencari sumber data dengan menggunakan FGD, wawancara, dan studi literatur.

\section{HASIL DAN PEMBAHASAN}

Pancasila secara material merupakan dasar negara Republik Indonesia (Budiman dan Hastangka, 2020). Hakikat Pancasila sebagai dasar negara diharapkan menjiwai seluruh aspek kehidupan bermasyarakat, berbangsa, dan bernegara. Upaya untuk memberikan pemahaman akan Pancasila sebagai dasar negara dapat dilakukan dengan berbagai cara dan model. Studi ini menunjukkan bahwa dalam perkembagannya materi dan metode menanamkan nilai nilai Pancasila mengalami perkembangannya. Untuk perguruan tinggi terdapat buku materi pembelajaran nilai Pancasila. Tujuan dari materi ini untuk menanamkan nilai nilai Pancasila dari aspek kognitif, psikomotorik, dan afektif melalui pendidikan. Materi dalam buku pembelajaran yang diterbitkan oleh DIKTI tahun 2016 antara lain mencakup Pancasila dalam arus sejarah bangsa, Pancasila menjadi dasar negara, Pancasila menjadi ideologi negara, Pancasila merupakan sistem filsafat, sistem etika, dan Pancasila menjadi dasar pengembangan ilmu (Dikti, 2016). Sedangkan konsepsi Badan Pembinaan Ideologi Pancasila (BPIP) memiliki standarisasi materi secara garis besar dibatasi oleh dua pemahaman. Pemahaman pertama adalah Pancasila bukanlah ideologi penguasa melainkan ideologi rakyat. Pancasila bukanlah milik penguasa melainkan milik rakyat. Meskipun penguasa berganti, Pancasila tetap menjadi acuan nilai-nilai dasar dalam berbangsa dan bernegara. Materi dasar versi BPIP mencakup sejarah lahirnya Pancasila, Pokok pokok pemikiran Pancasila oleh pendiri bangsa, kedudukan 
Pancasila dalam kehidupan berbangsa dan bernegara, demokrasi Pancasila, dan Pembangunan nasional berdasarkan Pancasila (BPIP,2020).

Problem penanaman nilai-nilai Pancasila bukan semata-mata sekedar masalah metode yang tidak menarik dan membosankan, melainkan juga mengenai perspektif paradigmatik dalam memandang dan memaknai Pancasila dan praksis pembelajaran. Pertama, Pancasila harus dilihat ulang tidak sebagai alat pemerintah untuk melanggengkan status quo, melainkan untuk membangun kedaulatan rakyat dan mewujudkan keadilan sosial. Kedua, penanaman nilai tidak dilihat sebagai proses transfer pengetahuan, nilai-nilai dan budaya dominan melainkan dipahami sebagai proses transformasi sosial. Ketiga, praksis pembelajarannya tidak sekedar mengetahui dan menguasai materi saja tetapi harus sampai pada melakukan dan mempraktekkan pengetahuan, nilai, budaya dan ideologi tersebut. Aspek Konatif ini sering dilupakan dalam penanaman nilai-nilai Pancasila.

Masyarakat adalah suatu entitas yang penting dalam membangun kehidupan berbangsa dan bernegara. Masyarakat sebagai salah satu bentuk dari unit negara terkecil yang memiliki peran peran dalam melakukan perubahan sosial dan politik di Indonesia. Masyarakat juga memiliki peran penting dalam membentuk karakter dan budaya. Masyarakat dapat diarikan sebagai kelompok atau komunitas yang dibangun atas individu individu dan memiiki peran dan fungsi sosial, politik, pendidikan, ekonomi, hukum, dan kebudayaan. Peraturan pemerintah Nomor 45 Tahun 2017 tentang Partisipasi Masyarakat dalam Penyelenggaraan Pemerintah Daerah menjelaskan tentang pengertian masyarakat. Pada pasal 1 ayat 2 Peraturan Pemerintah No 45/2017 tentang Partisipasi Masyarakat dalam Penyelenggaraan Pemerintah Daerah menjelaskan bahwa:"Masyarakat adalah orang perseorangan warga negara Indonesia, kelompok masyarakat, dan/atau Organisasi Kemasyarakatan". Secara yuridis konstitusional dapat dijelaskan bahwa masyarakat yang terdiri atas orang perorangan dan kelompok yang tinggal pada suatu wilayah tertentu. Masyarakat menjadi kelompok yang strategis dalam membangun kehidupan sosial dan budaya. Masyarakat sebagai individu, kelompok, dan komunitas memiliki peran penting dalam proses pembentukan nilai nilai. Untuk itu, proses pembentukan masyarakat diperlukan nilai nilai yang mendasar dan nilai nilai tersebut sudah ada di dalam kehidupan bangsa yaitu nilai budaya, nilai sosial, dan nilai nasional yang tercermin dalam Pancasila.

Keluarga memiliki berbagai macam definisi dan pengertian. Pengertian keluarga dipengaruhi oleh berbagai konsep. Konsep yang meletakkan pada asal usul atau biologis memberikan pengertian keluarga berasal dari hubungan sedarah atau sekandung dari hasil perkawinan yang sah. Komponen keluarga terdiri atas ayah, ibu, dan anak. Dalam konteks hukum negara, keluarga juga bisa diartikan sebagai unit terkecil yang terdiri atas ayah dan ibu dan anak baik dari hasil hubungan sedarah atau adopsi secara resmi oleh negara. Dalam Undang-Undang Nomor 52 Tahun 2009 tentang Perkembangan Kependudukan dan Pembangunan Keluarga pasal 1 ayat 6 menyatakan bahwa Keluarga adalah unit terkecil dalam masyarakat yang terdiri dari suami istri, atau suami, istri dan anaknya, atau ayah dan anaknya, atau ibu dan anaknya. Negara memberikan definisi tentang keluarga sebagai unit terkecil dalam masyarakat dan terdiri atas suami istri atau suami, istri, dan anaknya atau ayah dan anaknya, atau ibu dan anaknya (UU No 52/2009, pasal 1 ayat 6).

Pendidikan memiliki berbagai macam konsep dan jalur. Di Indonesia jalur pendidikan secara umum terbagi menjadi tiga kategori yaitu pendidikan formal, pendidikan non formal, dan pendidikan informal. Dalam konteks pendidikan informal jalur ini terdiri atas dua komponen yaitu keluarga dan masyarakat. Undang Undang Nomor 20 Tahun 2003 tentang Sistem Pendidikan Nasional pasal 1 ayat 13 ialah Pendidikan informal adalah jalur pendidikan keluarga dan lingkungan. Pendidikan informal menjadi bagian penting dalam proses pembentukan nilai nilai. Wujud dari pendidikan informal ialah meletakkan nilai nilai Pancasila dalam wujud umum dan 
konkret. Dalam wujud umum nilai nilai Pancasila sebagai pengetahuan dan wujud konkret diartikan bahwa nilai nilai Pancasila dalam praktek kehidupan sehari hari. Pancasila merupakan dasar falsafah negara dan pandangan hidup bangsa. Pancasila dalam konteks kehidupan ketatanegaraan diartikan sebagai dasar negara. Pancasila dijadikan sebagai dasar negara dengan alasan sebagai berikut:

1) Bahwa Pancasila yang telah dirumuskan oleh para pendiri bangsa yang diawali dengan pidato Soekarno telah disepakati sebagai dasar negara Indonesia merdeka.

2) Pancasila digali dari adat dan budaya bangsa Indonesia sebagai common denominator atau de grootste gemene deeler dari adat dan budaya bangsa Indonesia.

3) Pancasila sebagai dasar negara adalah fondasi bagi pembentukan negarabangsa

4) Pancasila sebagai dasar negara merupakan cita-cita negara (staatsidee) dan cita hukum (rechtsidee) yang berkembang menjadi staatsfundamentalnorm bersifat konstitutif dan regulatif.

5) Pancasila sebagai dasar negara adalah asas dari hukum positif yang berlaku di NKRI.

6) Pancasila sebagai dasar negara menjiwai UUD 1945 dalam mengatur penyelenggaraan negara serta menata kehidupan warga negara dalam bermasyarakat, berbangsa, dan bernegara (Sumber: Pitoyo, 2012:4).

Pancasila menjadi fondasi dalam kehidupan bermasyarakat, berbangsa, dan bernegara. dalam aspek sejarah, Pancasila merupakan dasar falsafah negara yang kemudian termaktub dalam pembukaan UUD 1945 pada alenia keempat. Secara yuridis penegasan Pancasila sebagai dasar negara dan pandangan hidup bangsa juga pernah dirumuskan dalam Ketetapan MPR RI No. II/MPR/1978 tentang Pedoman Penghayatan dan Pengamalan Pancasila (Eka Prasetia Pancakarsa) pada klausul menimbang poin a menjelaskan bahwa "Pancasila yang merupakan pandangan hidup Bangsa dan dasar Negara Republik Indonesia perlu dihayati dan diamalkan secara nyata untuk menjaga kelestarian dan keampuhannya demi terwujudnya tujuan Nasional serta cita-cita Bangsa seperti tercantum dalam Pembukaan Undang Undang Dasar 1945". Dalam Ketetapan MPR RI No II/MPR/1978 ini telah memberikan dasar yuridis konstitusional tentang hakikat dan kedudukan Pancasila dalam kehidupan berbangsa dan bernegara. Pancasila merupakan dasar falsafah negara dan pandangan hidup bangsa merupakan wujud penegasan negara dan pemerintah dalam meletakkan prinsip prinsip bernegara. Pancasila merupakan dasar negara. Makna dasar negara ini menjadi salah satu wujud nyata dalam proses pembentukan dan penguatan nilai nilai Pancasila dalam kehidupan bernegara.

Berdasarkan FGD yang diselenggarakan oleh Tim Kajian Materi dan Metode pada hari Sabtu, 28 November 2020 di Hotel D'Senopati menunjukkan beberapa temuan menarik terkait materi dan metode yang ada dan diharapkan oleh para narasumber dan peserta. Berikut ini fakta empirik yang muncul dalam FGD. Fakta empiris yang berkembang di keluarga dan masyarakat hari ini terungkap di dalam FGD bahwa masyarakat dan keluarga hari ini sudah kehilangan orientasi kebangsaan dan nilai nilai Pancasila. Sebagaimana dalam tabel di bawah ini: 


\begin{tabular}{|l|l|l|}
\hline No & Kategori & Deskripsi/Kondisi saat ini \\
\hline 1. & Keluarga & $\begin{array}{l}\text { Ibu rumah tangga kini tidak memahami Pancasila, bagaimana } \\
\text { bisa menanamkan nilai nilai Pancasila kepada keluarga atau } \\
\text { anaknya. }\end{array}$ \\
\hline $\begin{array}{l}\text { Para pensiunan PNS justru menjadi kadrun. } \\
\text { lbu ibu PKK didominiasi oleh ibu ibu yang berusia } 40 \text { tahun ke } \\
\text { bawah, yang notabene sudah tidak diajarkan nilai nilai } \\
\text { Pancasila. } \\
\text { Generasi muda telah didoktrin dalam bentuk agama keras dan } \\
\text { sering mengharamkan sesuatu seperti Hari Kartini } \\
\text { diharamkan, hari ibu diharamkan. Dampaknya generasi muda } \\
\text { kehilangan orientasi sejarah bangsanya, bawa roti tart } \\
\text { dianggap haram. }\end{array}$ \\
\hline 2. & Masyarakat & $\begin{array}{l}\text { Munculnya perumahan berbasis syariah seperti di Gunung } \\
\text { Kidul, Bantul, dan Kulon progo), siapa yang memberikan ijin? } \\
\text { Di masyarakat muncul praktek intoleransi seperti munculnya } \\
\text { kos kosan khusus muslim, kuburan khusus agama tertentu. }\end{array}$ \\
\hline
\end{tabular}

Tabel 1. Fakta Empiris dari FGD

Sumber: hasil olah data tim peneliti, 2020.

Fakta empirik yang muncul berdasarkan temuan hasil FGD tabel 1 di atas menjadi dasar berpijak perlunya suatu konsep dan desain penanaman nilai nilai Pancasila dalam kehidupan berbangsa dan bernegara dalam rangka pembinaan Ideologi Pancasila menjadi penting. Untuk usulan terkait dengan materi FGD muncul beberapa usulan awal terkait dengan materi untuk Pembinaan Ideologi Pancasila pada pendidikan informal (Keluarga dan Masyarakat) sebagai berikut:

1. Materi yang bersifat kontekstual dan praksis

2. Materi yang mengarahkan nasionalisme

3. Materi tentang Pancasila sebagai dasar negara

4. Materi tentang praktek kehidupan sehari hari

5. Materi yang memiliki konten Keseniaan kebudayaan Indonesia

6. Materi yang mengarahkan pada konten untuk UMKM berbasis Pancasila

7. Materi yang dapat meningkatkan lagi kesadaraan akan hari-hari nasional

8. Materi yang mendasarkan pada HIGHER ORDER THINKING memperhatikan literasi Budaya, Bahasa secara komprehensif.

A. Pokok Materi Pembinaan Ideologi Pancasila pada Pendidikan Informal

Deskripsi: Materi Pembinaan Ideologi Pancasila pada pendidikan Informal ( Keluarga dan Masyarakat) berdasarkan dari kajian dan pendalaman FGD tentang materi menunjukkan bahwa materi pembinaan ideologi Pancasila pada pendidikan Informal dirumuskan dalam bentuk yang kontekstual, aplikatif, konseptual, dan berpijak pada penguatan karakter dan jati diri bangsa. Pembinaan ideologi Pancasila pada pendidikan informal (Keluarga dan Masyarakat) yang dimaksud dalam rumusan tim kajian PSP UPN Veteran Yogyakarta adalah:

"Upaya secara sistematis dan terencana dalam penanaman nilai nilai Pancasila untuk memperkokoh Pancasila sebagai dasar negara dan pandangan hidup bangsa pada lingkungan keluarga dan masyarakat"

Untuk itu, konsepsi materi yang akan dirumuskan untuk Pembinaan Ideologi Pancasila pada pendidikan informal oleh tim kajian PSP UPN Veteran Yogyakarta menjadi dua bagian utama yaitu materi pembinaan ideologi Pancasila dalam ranah keluarga dan materi pembinaan ideologi Pancasila dalam ranah masyarakat sebagai berikut: 


\begin{tabular}{|c|c|c|}
\hline No & $\begin{array}{l}\text { Kategori } \\
\text { Kelompok } \\
\text { Sasaran }\end{array}$ & Deskripsi \\
\hline 1. & Keluarga & $\begin{array}{l}\text { 8 Fungsi Keluarga: } \\
\text { 1. Keagamaan (memperkuat nilai nilai Ketuhanan Yang Maha } \\
\text { Esa dan toleransi terhadap sesama serta antar umat } \\
\text { beragama) } \\
\text { 2. Sosial dan Budaya (cinta tanah air, cinta kebudayan } \\
\text { bangsa, bangga sebagai bangsa Indonesia, sopan santun, } \\
\text { bekerjasama, tolong menolong, sikap tenggang rasa/tepa } \\
\text { selira) Kasih (Empati, Akrab, adil, dan pemaaf, } \\
\text { 3. Cinta Kash } \\
\text { mempraktekkan nilai nilai Pancasila) } \\
\text { 4. Perlindungan (memberikan rasa aman, pemaaf, } \\
\text { peduli,tanggap akan lingkungan sekitar) } \\
\text { 5. Sosialisasi dan Pendidikan (membangun komunikasi antar } \\
\text { keluarga yang tangguh, terciptakan ketahanan keluarga } \\
\text { yang berkelanjutan berkarakter Pancasila dan } \\
\text { berkepribadian dalam kebudayaan, menyakini Pancasila } \\
\text { sebagai dasar negara dan pandangan hidup bangsa) } \\
\text { 6. Ekonomi (hemat, disiplin, peduli sesama) } \\
\text { 7. Reproduksi ( tanggung jawab, pemeliharaan) } \\
\text { 8. Lingkungan (melestarikan dan menjaga lingkungan dan } \\
\text { peduli terhadap kebersihan lingkungan dan mencintai alam } \\
\text { Indonesia }\end{array}$ \\
\hline 2. & Masyarakat & $\begin{array}{l}\text { Kisi kisi materi Pembinaan Ideologi Pancasila di Masyarakat } \\
\text { dalam bentuk } \\
\text { 1. Materi bersifat Kontekstual dan praksis } \\
\text { - Mendeskripsikan kondisi dan situasi keberagaman bangsa } \\
\text { Indonesia dari berbagai macam suku bangsa, agama, } \\
\text { budaya } \\
\text { - } \quad \text { Merasa memiliki akan bangsa Indonesia } \\
\text { - } \quad \text { Cinta tanah air dan budaya bangsa } \\
\text { - } \text { Membangun kesadaran kritis dan kebangsaan } \\
\text { 2. Materi tentang nasionalisme dan Kepancasilaan } \\
\text { - Pancasila menjadi dasar negara dan pandangan hidup } \\
\text { bangsa } \\
\text { - Meningkatkan kesadaran berbangsa dan bernegara } \\
\text { Menumbuhkan semangat cinta tanah air dan menghargai } \\
\text { berbagai macam perbedaan } \\
\text { Tidak bersifat diskriminatif } \\
\text { - Menghindari watak dan sikap intoleransi dan disintegrasi } \\
\text { bangsa (memberikan edukasi contoh contoh praktek } \\
\text { intoleran yang tidak Pancasilais; kos kosan muslim, } \\
\text { perumahan berbasis syariah, dll). }\end{array}$ \\
\hline
\end{tabular}

Tabel.2 Kerangka konseptual Perumusan Kisi kisi materi Pembinaan Ideologi Pancasila

Metode merupakan salah satu cara atau alat untuk mencapai tujuan tertentu. Pengertian lain tentang metode ialah merujuk pada jalur yang dilakui dalam melaksanakan kegiatan tertentu dari sudut pandang yang telah ditentukan dalam hal ini biasanya sudut pandang peneliti (Titscher,dkk, 2009:5). Dalam hal ini metode yang 
akan digunakan dalam rangka Pembinaan Ideologi Pancasila pada pendidikan informal (Keluarga dan Masyarakat) sebagai bentuk "Upaya secara sistematis dan terencana dalam penanaman nilai nilai Pancasila untuk memperkokoh Pancasila sebagai dasar negara dan pandangan hidup bangsa pada lingkungan keluarga dan masyarakat" dapat dirumuskan sebagai berikut:

Tabel.3. rumusan metode

\begin{tabular}{|c|c|c|c|}
\hline No & $\begin{array}{l}\text { Kategori } \\
\text { Kelompok } \\
\text { Sasaran }\end{array}$ & Deskripsi & Metode \\
\hline 1 & Keluarga & 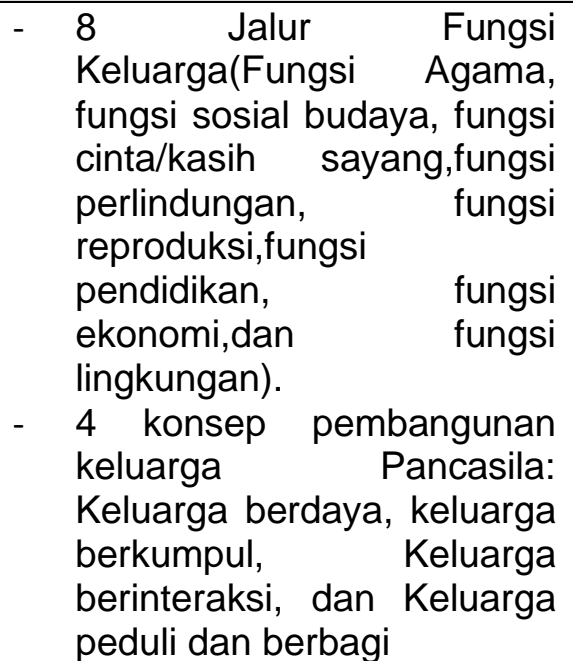 & $\begin{array}{ll}\text { - } & \text { Metode Pengasuhan } \\
\text { Asah, Asih, Asuh } \\
\text { - } \quad \text { Metode Kontekstua } \\
\text { Aplikatif Menyeluruh } \\
\text { - } \quad \text { Metode Atraktif } \\
\text { - } \quad \text { Metode Pengertian dan } \\
\text { tindakan }\end{array}$ \\
\hline 2 & Masyarakat & 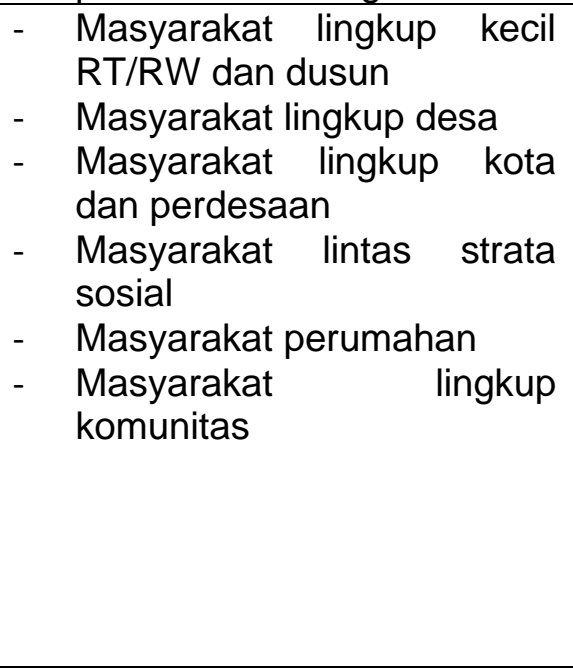 & $\begin{array}{l}\text { - } \text { Metode } \\
\text { sosialisasi/ceramah/dis } \\
\text { kusi } \\
\text { - } \text { Metode aplikatif } \\
\text { Berkebudayaan dan } \\
\text { Berkesenian } \\
\text { - } \text { Metode Kontekstual } \\
\text { Menumbuhkan } \\
\text { semangat berbangsa } \\
\text { dan bernegara } \\
\text { Metode tindakan } \\
\text { keteladanan, simbo } \\
\text { memastikan } \\
\text { simbol negara terdapat } \\
\text { di setiap rumah }\end{array}$ \\
\hline
\end{tabular}

Tabel.3. rumusan metode

Sumber: Olah data tim peneliti, 2020.

Berdasarkan hasil kajian tim materi dan metode Pembinaan Ideologi Pancasila yang telah dilakukan melalui Focus Group Discussion dan kajian teoritis dan empirik menunjukkan bahwa metode yang dapat digunakan untuk melakukan penanaman nilai nilai Pancasila dalam rangka Pembinaan Ideologi Pancasila pada pendidikan Informal (Keluarga dan Masyarakat) dalam dibuatkan skema dan alur sebagai berikut: 


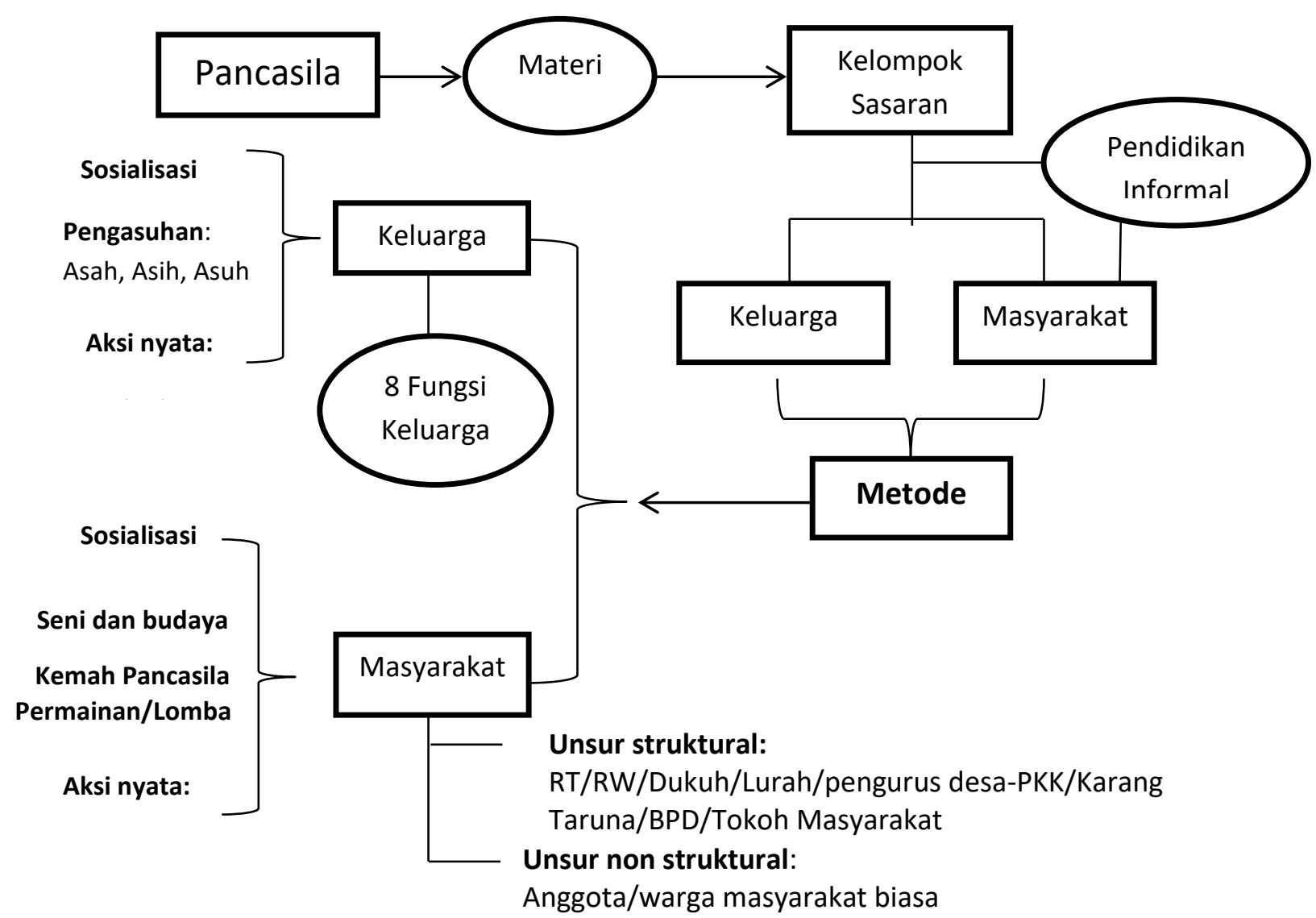

Bagan.1 Proses dan alur pembinaan nilai nilai Pancasila di masyarakat dan keluarga (sumber: hasil dari analisis peneliti, 2020)

Berdasarkan skema 1 di atas menunjukkan bahwa alur untuk melakukan penanaman nilai nilai Pancasila dalam rangka pembinaan ideologi Pancasila dapat dilakukan mulai perumusan materi yang disesuaikan dengan konteks zaman dan perkembangan masyarakat. Setelah fase perumusan materi kemudian dilakukan standarisasi secara formal untuk diberikan kepada kelompok sasaran yaitu masyarakat dan keluarga. Pada saat masuk pada kelompok sasaran masyarakat dan keluarga metode yang digunakan dapat digunakan sebagai upaya untuk melembagakan nilai nilai Pancasila pada level keluarga melalui 8 fungsi keluarga. Bentuk kegiatan yang dilakukan melalui sosialisasi, pengasuhan dan aksi nyata. Bentuk aksi nyata berupa kegiatan bersama, gotong royong, lomba, renungan harian keluarga Pancasila. Sedangkan pada level masyarakat melalui cara struktural dan non struktural. Bentuk kegiatan yang dilakukan secara terlembaga melalui sosialisasi, seni budaya, kemah Pancasila, dan aksi nyata dalam bentuk lomba dan kegiatan kelompok.

\section{SIMPULAN}

Berdasarkan dari hasil kajian ini menyimpulkan bahwa penanaman nilai nilai Pancasila dalam rangka pembinaan ideologi Pancasila pada pendidikan informal (keluarga dan masyarakat) dapat melalui beberapa metode. Metode untuk masyarakat dapat dilakukan melalui jalur struktural dan non struktural. Pada jalur ini kegiatan yang dapat dilakukan dalam bentuk sosialisasi, seni budaya, kemah Pancasila,dan kegiatan aksi nyata yang melibatkan keikutsertakan warga dan perangkat desa. Sedangkan untuk keluarga dapat dilakukan melalui 8 fungsi keluarga dapat berupa sosialisasi, pengasuhan (pembinaan keluarga dan anggota keluarga), dan aksi nyata berupa 
lomba, dan kegiatan yang dapat membangun anggota masyarakat mengenal Pancasila. Materi yang diharapkan oleh masyarakat berupa materi yang mendorong wawasan Pancasila secara kontekstual dan meletakkan Pancasila sebagai dasar negara.

\section{DAFTAR PUSTAKA}

Budiman.L., Hastangka.(2020). Buku Ajar Pendidikan Pancasila. Yogyakarta: LPPM UPN Veteran Yogyakarta.

BPIP.(2020). Materi Dasar Pembinaan Ideologi Pancasila. Jakarta: Kedeputian Bidang Pengkajian dan Materi.

Dikti.(2016). Buku Ajar Pendidikan Pancasila untuk Perguruan Tinggi. Jakarta: Direktorat Jenderal Pembelajaran dan Kemahasiswaan, Kementerian Riset, Teknologi, dan Pendidikan Tinggi.

Hamid,Edy Suandi.(2012).Peran Pendidikan untuk Mengukuhkan Nasionalisme dan Membangun Karakter Bangsa, UNISIA, Vol. XXXIV No. 76 Januari 2012, hal.40-46.

Ketetapan MPR RI No II/MPR/1978 tentang Pedoman Penghayatan dan Pengamalan Pancasila (Eka Prasetia Pancakarsa).

Octavia, Erna., Rube'l, M. Anwar.(2017). Penguatan Pendidikan Karakter Berbasis Pancasila Untuk Membentuk Mahasiswa Prodi PPkn Menjadi Warga Negara Yang Baik Dan Cerdas, SOSIAL HORIZON: Jurnal Pendidikan Sosial Vol. 4, No. 1, Juni 2017, hal.111-124.

Omeri.Nopan.(2015). Pentingnya Pendidikan Karakter Dalam Dunia Pendidikan, Manajer Pendidikan, Volume 9, Nomor 3, Juli 2015, hlm. 464-468.

Pitoyo,dkk. 2012. Pancasila Dasar Negara. Yogyakarta: PSP UGM.

Peraturan pemerintah Nomor 45 Tahun 2017 tentang Partisipasi Masyarakat dalam Penyelenggaraan Pemerintah Daerah.

Titscher, Stefan dkk.(2009). Metode Analisis Teks \& Wacana, Terj. Gazali, dkk., Yogyakarta: Pustaka Pelajar.

Undang-Undang Nomor 52 Tahun 2009 tentang Perkembangan Kependudukan dan Pembangunan Keluarga.

Undang Undang Nomor 20 Tahun 2003 tentang Sistem Pendidikan Nasional. 